\title{
ANALISIS REALISASI PENGELOLAAN DANA DESA DI PEKON KUSA KECAMATAN KOTA AGUNG TAHUN 2018
}

\author{
Juliono, Kartika Rastiwi
}

Program Studi Manajemen, Fakultas Ekonomi dan Bisnis Universitas Muhammadiyah Pringsewu

Jl. Makam Kh. Ahmad Dahlan no.112 Lampung Tengah Lampung 35373

\section{Email : djuliono@umpri.ac.id , kartikarastiwi@umpri.ac.id}

\begin{abstract}
Abstrak
Pengelolaan Keuangan Desa adalah keseluruhan kegiatan yang meliputi perencanaan, pelaksanaan, penatusahaan, pelaporan dan pertanggungjawaban keuangan desa. Tujuan penelitian ini adalah untuk mengetahui apakah Pengelolaan Dana Desa di Pekon Kusa sudah sesuai dengan Permendagri Nomor 113 Tahun 2014. Penelitian ini dilakukan di Pekon Kusa, Kecamatan Kota Agung, Kabupaten Tanggamus.

Jenis penelitian ini merupakan studi kasus. Metode penelitian dilakukan dengan teknik deskriptif. Teknik analisis data yang digunakan yaitu dengan: 1) Pengumpulan data 2) Reduksi data 3) Penyajian data 4) analisis (pembahasan), dengan cara membandingkan dokumendokumen yang terkait antara pengeloaan dana Desa di Pekon Kusa Kecamatan Kota Agung dengan Peraturan Menteri Dalam Negeri Nomor 113 Tahun 2014 tentang Pengelolaan Keuangan Desa. 5) Penarikan kesimpulan dalam penelitian ini berupa teks naratif tentang pengelolaan dana desa di Pekon Kusa Kecamatan Kota Agung.

Hasil penelitian menunjukkan pengelolaan Dana Desa Di Pekon Kusa secara umum sudah sesuai dengan Peraturan Menteri Dalam Negeri Nomor 113 Tahun 2014. Namun masih ada beberapa ketentuan yang belum dilakukan. Pertama, pada proses perencanaan keuangan desa masih mengalami keterlambatan dalam menetapkan Anggaran Pendapatan dan Belanja Desa karena ada peraturan baru yang muncul sehingga diperlukan penyesuaian. Selanjutnya pada proses pelaksanaan, dalam pengeluaran desa belum semua dilakukan melalui rekening kas desa. Selain itu, pada proses pelaporan dan pertanggungjawaban juga mengalami keterlambatan dalam penyampaian laporan realiasi pelaksanaan dan pertanggungjawaban keuangan desa belum di informasikan kepada masyarakat melalui media social ataupun media lainnya
\end{abstract}

Kata Kunci : Pengelolaan, Realisasi, Dana Desa 


\section{PENDAHULUAN}

Pengelolaan Keuangan Desa adalah keseluruhan kegiatan yang meliputi perencanaan, pelaksanaan, penatusahaan, pelaporan dan pertanggungjawaban keuangan desa. Pengelolaan keuangan yang dimaksud adalah pengelolaan Anggaran Pendapatan dan Belanja Desa (APBDes) untuk mendukung dan menjalankan program-progam kerja Pemerintah Desa yang telah direncanakan. APBDes adalah rencana keuangan Tahunan Pemerintah Desa.

Pengelolaan Dana Desa diperlukan agar dipergunakan tepat sasaran dan digunakan untuk kepentingan pembangunan dan pemberdayaan Masyarakat untuk mewujudkan Desa yang mandiri, maju, dan demokratis. Pengelolaan keuangan Desa yang baik adalah pengelolaan yang sesuai dengan pedoman yang telah diatur oleh Pemerintah yakni telah tertuang pada Peraturan Menteri Dalam Negeri Nomor 113 Tahun 2014 tentang pengelolan keuangan Desa. Pengelolaan Keuangan Desa secara keseluruhan disusun dengan lima tahap yaitu, tahap perencanaan, tahap pelaksanaan, tahap penatausahaan, tahap pelaporan dan tahap pertanggungjawaban keuangan desa. Dalam hal Keuangan Desa, Pemerintah Desa wajib menyusun Laporan Realisasi Pelaksanaan APBDes dan Laporan Pertanggungjawaban Realisasi Pelaksanaan APBDes

Pekon Kusa Kecamatan Kota Agung Kabupaten Tanggamus, merupakan salah satu pekon diwilayah kecamatan kota agung kabupaten tanggamus. Pada tahun 2018 dana Desa di Pekon Kusa sebesar Rp. 930.356.741 yang bisa digunakan oleh pemerintah desa dalam melaksanakan program pembangunan dan pemberdayaan. Besamya jumlah anggaran yang diterima, memerlukan Pengelolaam yang baik dan benar karena dengan adanya laporan keuangan yang handal sangat diharapkan sebagai wujud pertanggungjawaban kepada masyarakat itu sendiri. Akan tetapi, pada kenyataannya di Pekon Kusa masih ditemukan adanya ketimpangan antara aturan dengan praktiknya dalam pengelolaan keuangan desa. Pada tahap pertanggungjawaban belum adanya publikasi atau transparansi. Laporan pertanggungjawaban secara tertulis belum diinformasikan kepada masyarakat dan melalui media papan pengumuman, atau melalui media lainnya.

\section{LANDASAN TEORI}

Keuangan Desa adalah semua hak dan kewajiban dalam rangka penyelenggaraan pemerintah Desa yang dapat dinilai dengan uang, termasuk didalamnya dalam bentuk kekayaan yang berhubungan dengan hak dan kewajiban Desa tersebut. (Permendagri Nomor 113 tahun 2014).

Pengelolaan keuangan Desa adalah keseluruhan kegiatan yang meliputi: Perencanaan, Pelaksanaan, Penatausahaan, Pelaporan dan Pertanggungjawaban. (Sujarweni, 2015: 17). Dalam pelaksanaannya, Pemerintah Desa wajib mengelola keuangan Desa secara transparan, akuntabel, dan partisipatif. Transparan berarti dikelola secara terbuka, akuntabel berarti dipertanggungjawabkan secara hukum, dan partisipatif bermakna melibatkan masyarakat dalam prosesnya. Disamping itu, keuangan Desa harus dibukukan dan dilaporkan sesuai dengan kaidah sistem akuntansi keuangan pemerintahan. 
a. Azaz Pengelolaan Keuangan Desa

1) Transparan

Menurut Nordiawan dalam (V. Wiratna Surjaweni, 2015:28). Transparan adalah memberikan informasi keuangan yang terbuka dan jujur kepada masyarakat berdasarkan pertimbangan bahwa masyarakat memiliki hak untuk mengetahui secara terbuka dan meneyeluruh atas pertanggungjawaban pemerintah dalam pengelolaan sumber daya yang dipercayakan kepadanya dan ketaatannya pada peraturan perundang-undangan. Transparan adalah prinsip yang menjamin akses atau kebebasan bagi setiap orang untuk memperoleh informasi tentang penyelenggaraan pemerintahan, yakni informasi tentang kebijakan, proses pembuatan dan pelaksanaannya serta hasilhasil yang dicapai.

b) Akuntabel

Tata kelola pemerintahan yang baik merupakan salah satu tuntunan masyarakat yang harus dipenuhi. Salah satu pilar tata kelola tersebut adalah akuntabilitas.

Menurut Sabeni dan Ghozali dalam ( V. Wiratna Surjaweni, 2015:28) Akuntabilitas atau pertanggungjawaban (accountability) merupakan suatu bentuk keharusan seorang pemimpin / pejabat/ pelaksana untuk menjamin bahwa tugas dan kewajiban yang diembannya sudah dilaksanakan sesuai ketentuan yang berlaku. Akuntabilitas dapat dilihat melalui laporan tertulis yang informative dan transparan.

c) Partisipatif

Partisipatif adalah prinsip dimana bahwa setiap warga desa pada desa yang bersangkutan mempunyai hak untuk terlibat dalam setiap pengambilan keputusan pada setiap kegiatan yang diselenggarakan oleh pemerintah desa dimana mereka tinggal. Keterlibatan masyarakat dalam rangka pengambilan keputusan tersebut dapat secara langsung dan tidak langsung. (V. Wiratna Surjaweni , 2015:29). d) Tertib dan Disiplin Anggaran

Tertib dan disiplin anggaran yaitu pengelolaan keuangan desa harus mengacu pada aturan atau pedoman yang melandasinya.

\section{b. Siklus Pengelolaan Keuangan Desa}

Siklus atau tahapan pengelolaan keuangan Desa berdasarkan Peraturan Menteri Dalam Negeri Nomor 113 Tahun 2014 sebagai berikut :

1) Perencanaan

Perencanaan meliputi aktivitas yang sifatnya strategik, taktis, dan melibatkan aspek operasional. Proses perencanan juga melibatkan aspek prilaku yaitu partisipasi dalam pengembangan sistem perencanaan, penetapan tujuan, dan pemilihan alat yang paling tepat untuk memonitor perkembangan pencapaian tujuan.

Mekanisme perencanaan pengelolaan keuangan desa berdasarkan Permendagri nomor 113 tahun 2014 adalah sebagai berikut:

a) Sekertaris Desa menyusun rancangan peraturan Desa tentang APBDes berdasarkan RKPDesa. Kemudian Sekretaris Desa menyampaikan kepada Kepala Desa.

b) Rancangan peraturan Desa tentang APBDesa disampaikan Kepala Desa kepada Badan Permusyawaratan Desa untuk pembahasan lebih lanjut dan disepakati bersama, dan kesepakatan tersebut paling lambat bulan Oktober tahun berjalan.

c) Rancangan peraturan Desa tentang APBDesa yang telah disepakati bersama, akan disampaikan oleh Kepala Desa kepada Bupati/Walikota melalui Camat atau sebutan lain paling lambat 3 hari sejak disepakati untuk dievaluasi. Kemudian Bupati/Walikota menempatkan hasil evaluasi rancangan 
APBDesa paling lambat 20 hari kerja sejak diterimanya rancangan peraturan Desa tentang APBDesa. Jika dalam waktu 20 hari kerja Bupati/Walikota tidak memberikan hasil evaluasi maka peraturan desa tersebut berlaku dengan sendirinya.

d) Apabila Bupati/Walikota menyatakan hasil evaluasi rancangan peraturan Desa tentang APBDesa tidak sesuai dengan kepentingan umum dan peraturan perundang-undangan yang lebih tinggi, maka Kepala Desa melakukan penyempumaan paling lam 7 hari kerja terhitung sejak diterimanya evaluasi.

e) Apabila hasil evaluasi tidak ditindaklanjuti oleh Kepala Desa dan Kepala Desa tetap menempatkan rancangan peraturan Desa tentang APBDes menjadi peraluran desa, Bupati/Walikota dapat membatalkan peraturan Desa tersebut dengan keputusan Bupati/Walikota sekaligus menyatakan berlakunya pagu APBDesa tahun anggran sebelumya. Maka Kepala Desa hanya dapat melakukan pengeluaran terhadap operasional penyelenggaraan Pemerintah Desa dan harus menghentikan pelaksanaan peraturan Desa paling lama 7 hari kerja setelah pembatalan dan selanjutnya Kepala Desa bersama BPD mencabut peraturan Desa dimaksud.

f) Camat menetapkan hasil evaluasi rancangan APBDesa paling lama 20 (dua puluh) hari kerja sejak diterimanya rancangan peratuan Desa tentang APBDesa. Jika Camat tidak memberikan hasil evaluasi dalam batas waktu tersebut, maka peraturan Desa tersebut berlaku dengan sendirinya.

2) Pelaksanaan

Berkenaan dengan pelaksanaan keuangan Desa, Undang-undang Nomor 6 tahun 2014 tentang Desa menyatakan bahwa Kepala Desa adalah pemegang kekuasaan pengelolaan keuangan Desa yang dalam pelaksanaannya dibantu oleh perangkat Desa. Secara teknis pelaksanaan pcngclolaan kcuangan Desa diatur dalam Permendagri nomor 113 tahun 2014 (V. Wiratna Sujarweni, 2015; 19-21) yaitu sebagai berikut:

a) Pemerintah Desa dilarang melakukan pungutan sebagai penerimaan Desa selain yang ditetapkan dalam peraturan Desa.

b) Bendahara dapat menyimpan uang dalam kas Desa pada jumlah tertentu dalam rangka memenuhi kebutuhan operasinal pemerintah Desa.

c) Pengaturan jumlah uang dalam kas Desa ditetapkan dalam peraturan Bupati/Walikota.

d) Pengeluaran Desa yang mengakibatkan beban pada APBDesa tidak dapat dilakukan sebelum rancangan peraturan desa tentang APBDesa ditetapkan menjadi peraturan Desa.

e) Pengeluaran Desa tidak termasuk untuk belanja pegawai yang bersifat mengikat dan operasional perkantoran yang ditetapkan dalam peraturan Kepala Desa.

f) Penggunaan biaya tak terduga terlebih dulu harus dibuat rincian anggaran biaya yang telah disahkan oleh Kepala Desa.

g) Pelaksana kegiatan yang mengajukan pendanaan untuk melaksanakan kegiatan harus disertai dengan dokumen antara lain Rencana Anggaran Biaya (RAB).

h) Rencana anggaran biaya diverifikasi oleh Sekertaris Desa dan disahkan oleh Kepala Desa.

i) Pelaksa na kegiatan bertanggungjawab terhadap tindakan pengeluaran yang menyebabkan atas beban anggaran belanja kegiatan dengan mempergunakan buku pembantu kas 
kegiatan sebagai pertanggungjawaban pelaksanaan kegiatan di Desa.

j) Pelaksana kegiatan mengajukan Surat Permintaan Pembayaran (SPP) kepada Kepala Desa. SPP tidak boleh dilakukan sebelum barang dan atau jasa diterima. Pengajuan SPP terdiri atas Surat Permintaan Pembayaran (SPP), pernyataan tanggimgjawab belanja dan lampiran bukti transaksi.

k) Berdasarkan SPP yang telah diverifikasi Sekretaris Desa kemudian Kepala Desa menyetujui permintaan pembayaran dan Bendahara melakukan pembayaran.

1) Pembayaran yang telah dilakukan akan dicatat Bendahara.

m) Bendahara Desa sebagai wajib Pungut Pajak Penghasilan ( $\mathrm{PPh})$ dan pajak lainnya, wajib menyelorkan seluruh penerimaan potongan dan pajak yang dipungutnya ke rekening kas Negara sesuai dengan ketentuan peraturan perundang-undangan.

3) Penatausahaan

Tahap ini merupakan proses pencatatan seluruh transaksi keuangan yang terjadi dalam satu tahun anggaran. Kegiatan penatausahaan keuangan mempunyai fungsi pengendalian terhadap APBDesa. Hasil dari penatausahaan adalah laporan yang dapat digunakan untuk pertanggungjawaban pengelolaan keuangan.

Laporan pertanggungjawaban yang wajib dibuat oleh Bendahara Desa berdasarkan Permendagri Nomor 113 tahun 2014 adalah sebagai berikut:

a) Buku Kas Umum

Buku kas umum digunakan untuk mencatat berbagai aktivitas yang menyangkut penerimaan dan pengeluaran kas, baik secara tunai maupun kredit, digunakan juga untuk mencatat mutasi perbankan atau kesalahan dalam pembukuan. Buku kas umum dapat dikatakan sebagai sumber dokumen transaksi.

b) Buku Kas Pembantu Pajak

Buku pajak digunakan untuk membantu buku kas umum, dalam rangka penerimaan dan pengeluaran yang berhubungan dengan pajak.

c) Buku Kas Bank

Buku kas bank digunakan untuk membantu buku kas umum, dalam rangka penerimaan dan pengeluaran

4) Pelaporan yang berhubungan dengan uang bank.

Pelaporan keuangan Desa merupakan alat evaluasi karena menyediakan informasi keuangan serta menunjukkan kinerja yang telah dilakukan sehingga nantinya akan menjadi bahan pertimbangan dalam pcngambilan keputusan ekonomi bagi Kepala Desa sendiri maupun pemangku kepentingan lainnya. Laporan pertanggungjawaban realisasi pelaksanaan APBDesa setiap akhir tahun anggaran disampaikan kepada Bupati atau Walikota melalui camat setelah Pemerintah Desa dan BPD telah sepakat terhadap laporan pertanggungjawaban realisasi pelaksanaan APBDesa dalam bentuk peraturan desa. (Permendagri nomor 113 tahun 2014).

\section{METODOLOGI PENELITIAN}

Metode Penelitian yang digunakan dalam penelitian ini adalah Penelitian Deskriptif. Penelitian yang dilakukan bertujuan untuk memberikan gambaran mengenai pengelolaan keuangan Desa berdasarkan Peraturan Menteri Dalam Negeri Nomor 113 tahun 2014 di Pekon Kusa Kecamatan Kota Agung Kabupaten Tanggamus. Objek penelitian adalah laporan realisasi dana desa pekon Kusa Kecamatan Tanggamus dan waktu pelaksanaan penelitian pada tahun 2019. Data yang digunakan dalam penelitian ini adalah dokumentasi, dimana dokumentasi termasuk kedalam data Primer. Data primer 
adalah data yang diperoleh langsung dari sumbernya, sumber data dalam penelitian ini diperoleh dari Laporan Keuangan Pengelolaan Dana Desa di Pekon Kusa. Adapun teknik analisis data yang dilakukan dalam penelitian ini adalah dengan cara menganalisis lima indikator yaitu Perencanaan, Pelaksanaan, Penatausahaan, Pelaporan, Pertanggungjawaban, Kemudian menyesuaikan pelaksanaannya sesuai dengan aturan pemerintah yaitu Permendagri 113 Tahun 2014 tentang Pengelolaan Keuangan Desa.

Berikut tahapan-tahapan dalam teknik analisis data penelitian dengan metode deskriptif :

1. Pengumpulan data, dimana peneliti mencatat data yang diperoleh sesuai dengan hasil wawancara, dan dokumentasi.

2. Reduksi data, Proses pemilihan data yang muncul dari catatan mengenai halhal yang ada di lapangan, sehingga peneliti dapat memilih data yang diperlukan untuk pengelolaan dana desa, langkah ini bertujuan untuk memilih informasi yang sesuai dengan masalah penelitian. Reduksi data dilakukan untuk menghasilkan data yang lebih tepat dan jelas, mempermudah peneliti untuk melakukan pengumpulan data yang selanjutnya.

3. Penyajian data, dilakukan dalam bentuk uraian singkat sehingga dapat memudahkan peneliti untuk memahami kondisi yang terjadi dan dapat menentukan tahap selanjutnya yang akan dikerjakan. Penyajian dalam bentuk uraian naratif pada langkah ini, data yang relevan disusun sehingga menjadi informasi yang dapat disimpulkan.

4. Kemudian dilakukan analisis (pembahasan), dengan cara membandingkan dokumen-dokumen yang terkait antara pengeloaan dana Desa di Pekon Kusa Kecamatan Kota Agung dengan Peraturan Menteri Dalam Negeri Nomor 113 Tahun 2014 tentang Pengelolaan Keuangan Desa.

5. Penarikan kesimpulan dalam penelitian ini berupa teks naratif tentang pengelolaan dana desa di Pekon Kusa Kecamatan Kota Agung.

\section{PEMBAHASAN DAN HASIL}

pada bagian ini akan dideskripsikan hasil penelitian. Analisis data untuk menjawab rumusan masalah tentang bagaimana realisasi pengelolaan dana desa di pekon kusa sesuai dengan Peraturan Menteri Dalam Negeri Nomor 113 Tahun 2014. Berikut Teknik analisis data deskriptif pada penelitian.

\section{a. Pengelolaan Keuangan Dana Desa}

a. Perencanaan

Perencanaan Anggaran Pendapatan dan Belanja desa di pekon kusa diawali dengan Musyawarah Pedukuhan (Musduk) yang dilakukan paa blan juni-juli setiap tahunnya. Musyawarah Pedukuhan tersebut melibatkan RT, RW, Tokoh agama dan PKK. Kegiatan ini bertujuan menyaring aspirasi Masyarakat pedukuhan. Kesepakatan yang diperoleh dalam Musyawarah Pedukuhan (Musduk) akan dibawa dalam Musyawarah Desa (Musdes) yang dilakukan pada bulan Agustus pada setiap Tahunnya. Dalam pelaksanaan musyawarah desa (Musdes) bertujuan untuk menghasilkan Rencana Kerja Pemerintah Desa (RKPDesa). Setelah itu, Sekretaris desa akan menyusun Rancangan Anggaran Pendapatan dan Belanja Desa (RAPBDesa) berdasarkan RKPDesa yang telah disepakati. Lalu pada bulan oktober 
sekertaris desa menyerahkan RAPDesa tersebut kepada kepala desa. Proses selanjutnya Kepala Desa akan menyampaikan RAPDesa kepada Badan Permusyawaratan Desa (BPD) untuk dibahasa dan disepakati bersama kemudian disampaikan kepada Bupati melalui Camat. Jika RAPBDesa telah disetujui oleh Bupati akan dilakukan pengesahan RAPDesa melalui sidang dengan BPD.

b. Pelaksanaan

Pelaksanaan pengelolaan keuangan di Pekon Kusa dimulai dari masingmasing kepala Seksi (Kasi) mengajukan surat perintah pembayaran (SPP) yang dilampiri dengan rencana Anggaran Biaya (RAB) yang ditujukan kepada kepala desa melalui sekretaris desa. Proses selanjutnya surat permintaan pembayaran tersebut akan mendapat pengesahan kepala desa. Lalu masing-masing Kasi akan mengajukan ke bendahara untuk mendapatkan dana. Kemudian bendahara mencatat sebagai pengeluaran desa.

c. Penatausahaan

Penatausahaan Pengelolaan Keuangan di Pekon Kusa dilakukan oleh bendahara Desa. Bendahara desa mencatat setiap pendapatan dan pengeluaran desa, dan melakukan tutup buku setiap akhir bulan. Selain itu juga bendahara desa melaporkan pertanggungjawaban keuangan desa kepada kepala desa paling lambat minggu pertama pada bulan berikutnya.

d. Pelaporan
Pelaporan APBDesa dipekon kusa diawali dengan pembuatan laporan pertanggungjawaban oleh setiap kepala seksi (Kasi) dan juga tim pelaksana. Laporan pertanggungjawaban tersebut diberikan kepada bendahara desa, yang akan digunakan sebagai dasar dalam pembuatan lapoan Realisai APBDesa. Laporan Realisasi APBDesa emudian disepakati bersama dengan BPD. Setelah itu kepala desa menyampaikan laporan Realisasi APBDesa kepada Bupati melalui Camat.

e. Pertanggungjawaban

Proses Pertanggungjawaban keuangan dipekon kusa dilakukan oleh kepala desa dengan melaporkan kepada bupati melalui camat. Selain itu kepala desa juga melaporkan kepada perwakilan masyarakat dan lembaga desa. Pemerintah Pekon Kusa juga menggunakan banner untuk melaporkan pertanggungjawaban APBDesa.

\section{b. Perbandingan Pengelolaan Dana Desa di Pekon Kusa dengan Peraturan Menteri Dalam Negeri Nomor 113 Tahun 2014}

1) Perencanaan

Tabel 1 : Perbandingan Perencanaan Dana Desa di Pekon Kusa dengan Peraturan Menteri Dalam Negeri Nomor 113 Tahun 2014

\begin{tabular}{|l|ll|c|c|}
\hline No & $\begin{array}{c}\text { Permendagri No } \\
113 \text { Tahun 2014 }\end{array}$ & $\begin{array}{c}\text { Realisasi } \\
\text { Pengelolaan } \\
\text { Dana Desa } \\
\text { di Pekon } \\
\text { Kusa }\end{array}$ & $\begin{array}{c}\text { Sesuai } \\
\text { Tidak } \\
\text { sesuai }\end{array}$ \\
\hline 1 & $\begin{array}{l}\text { Sekretaris Desa } \\
\text { menyusun }\end{array}$ & $\begin{array}{l}\text { Sekretaris } \\
\text { Desa telah }\end{array}$ & Sesuai \\
\hline
\end{tabular}




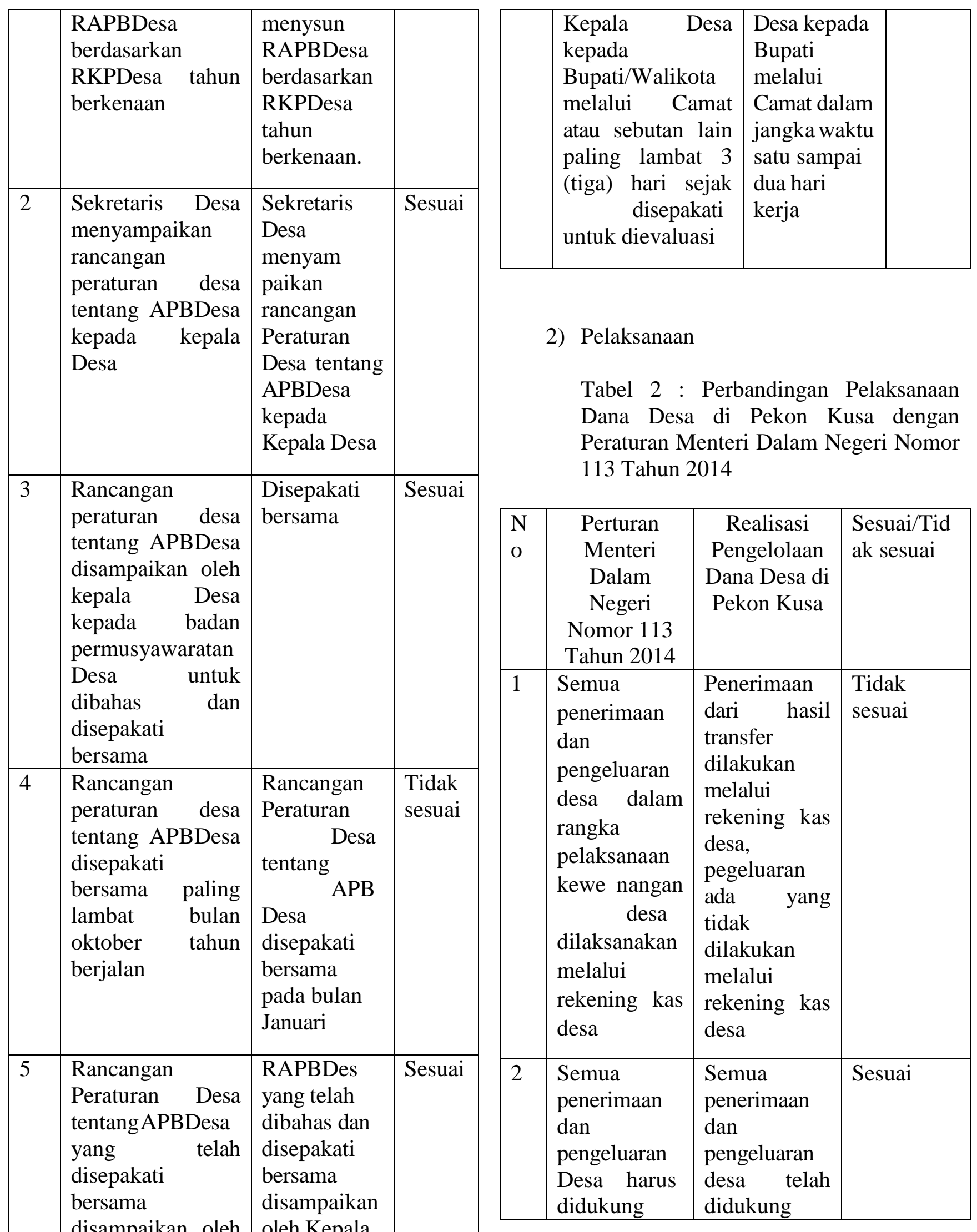




\begin{tabular}{|c|c|c|c|}
\hline & $\begin{array}{l}\text { oleh bukti } \\
\text { yang lengkap } \\
\text { dan sah }\end{array}$ & $\begin{array}{l}\text { oleh bukti } \\
\text { yang lengkap } \\
\text { dan sah }\end{array}$ & \\
\hline 3 & $\begin{array}{l}\text { Pemerintah } \\
\text { desa dilarang } \\
\text { melakukan } \\
\text { pungutan } \\
\text { sebagai } \\
\text { penerimaan } \\
\text { desa selain } \\
\quad \text { yang } \\
\text { ditetapkan } \\
\text { dalam } \\
\text { peraturan } \\
\text { desa }\end{array}$ & Pemerintah & Sesuai \\
\hline 4 & $\begin{array}{l}\text { Bendahara } \\
\text { dapat } \\
\text { menyimpan } \\
\text { uang dalam } \\
\text { Kas Desa } \\
\text { pada }\end{array}$ & $\begin{array}{l}\text { Bendahara } \\
\text { Desa } \\
\text { menyimpan } \\
\text { uang kas } \\
\text { desa dengan } \\
\text { nominal } \\
\text { tertentu }\end{array}$ & Sesuai \\
\hline 5 & Pengeluaran & Pengeluaran & Sesuai \\
\hline
\end{tabular}

3) Penatausahaan

Tabel 3 : Perbandingan Penatausahaan Dana Desa di Pekon Kusa dengan Peraturan Menteri Dalam Negeri Nomor 113 Tahun 2014

\begin{tabular}{|c|c|c|c|}
\hline $\begin{array}{l}\mathrm{N} \\
\mathrm{O}\end{array}$ & $\begin{array}{c}\text { Perturan } \\
\text { Menteri dalam } \\
\text { negeri nomor } \\
113 \text { tahun } 2014\end{array}$ & $\begin{array}{c}\text { Realisasi } \\
\text { Pengelolaan } \\
\text { Dana Desa di } \\
\text { Pekon Kusa }\end{array}$ & $\begin{array}{l}\text { Sesu } \\
\text { ai/ } \\
\text { tidak } \\
\text { sesua } \\
\text { i }\end{array}$ \\
\hline 1 & $\begin{array}{l}\text { Penatausahaan } \\
\text { dilakukan oleh } \\
\text { Bendahara Desa }\end{array}$ & $\begin{array}{l}\text { Bendahara } \\
\text { Desa melakukan } \\
\text { penatausahaan } \\
\text { keuangan desa }\end{array}$ & $\begin{array}{l}\text { Sesu } \\
\text { ai }\end{array}$ \\
\hline 2 & $\begin{array}{l}\text { Bendahara Desa } \\
\text { wajib } \\
\text { melakukan } \\
\text { pencatatan }\end{array}$ & $\begin{array}{l}\text { Bendahara } \\
\text { Desa melakukan } \\
\text { pencatatan }\end{array}$ & $\begin{array}{l}\text { Sesu } \\
\text { ai }\end{array}$ \\
\hline
\end{tabular}

\begin{tabular}{|c|c|c|c|}
\hline & $\begin{array}{l}\text { setiap } \\
\text { penerimaan dan } \\
\text { pengeluaran } \\
\text { serta melakukan } \\
\text { tutup buku } \\
\text { setiap akhir } \\
\text { bulan secara } \\
\text { tertib }\end{array}$ & $\begin{array}{l}\text { etiap } \\
\text { penerimaan }\end{array}$ & \\
\hline 3 & $\begin{array}{l}\text { Bendahara } \\
\text { Desar wajib } \\
\text { mempertanggun } \\
\text { g- jawabkan } \\
\text { uang melalui } \\
\text { laporan } \\
\text { pertanggungjaw } \\
\text { aban }\end{array}$ & $\begin{array}{l}\text { Bendahara } \\
\text { Desa } \\
\text { mempertanggun } \\
\text { g- jawabkan } \\
\text { uang melalui } \\
\text { aporan } \\
\text { pertanggungjaw } \\
\text { aban (LPJ) }\end{array}$ & $\begin{array}{l}\text { Sesu } \\
\text { ai }\end{array}$ \\
\hline 4 & \begin{tabular}{lr}
\multicolumn{2}{l}{ Laporan } \\
pertanggungjaw \\
a & ban \\
& disamp \\
aikan & setiap \\
bulan & kepada \\
Kepala & Desa \\
ling & \\
\multicolumn{3}{c}{ lambat } \\
tanggal & 10 \\
\multicolumn{3}{c}{ bulan } \\
berikutnya
\end{tabular} & $\begin{array}{l}\text { Bendahara } \\
\text { esa } \\
\text { menyampaikan } \\
\text { laporan kepada } \\
\text { Kepala Desa, } \\
\text { paling lambat } \\
\text { tanggal } 10 \text { bulan } \\
\text { berikutnya }\end{array}$ & $\begin{array}{l}\text { Sesu } \\
\text { ai }\end{array}$ \\
\hline
\end{tabular}

Sumber : Data Diolah (2020)

d. Pelaporan

Tabel 4: Perbandingan Pelaporan Dana Desa di Pekon Kusa dengan Peraturan Menteri Dalam Negeri Nomor 113 Tahun 2014

\begin{tabular}{|c|c|c|c|}
\hline N & Perturan & Realisasi & Sesuai \\
o & $\begin{array}{c}\text { Menteri dalam } \\
\text { negeri nomor } \\
113 \text { tahun 2014 }\end{array}$ & $\begin{array}{c}\text { Pengelolaan } \\
\text { Dana Desa di } \\
\text { Pekon Kusa }\end{array}$ & $\begin{array}{c}\text { / Tidak } \\
\text { sesuai }\end{array}$ \\
\hline 1 & Kepala & $\begin{array}{l}\text { Kepala Desa } \\
\text { telah }\end{array}$ & Sesuai \\
\hline
\end{tabular}




\begin{tabular}{|c|c|c|c|}
\hline & $\begin{array}{l}\text { menyam paikan } \\
\text { laporan realisasi } \\
\text { pelaksanaan } \\
\text { APBDesa } \\
\text { kepada } \\
\text { Bupati/Walikot } \\
\text { a berupa (a) } \\
\text { laporan } \\
\text { semester } \\
\text { pertama dan (b) } \\
\text { laporan } \\
\text { semester akhir } \\
\text { tahun }\end{array}$ & $\begin{array}{l}\text { menyampaika } \\
\mathrm{n} \quad \text { laporan } \\
\text { realisasi } \\
\text { pelaksanaan } \\
\text { APBDes } \\
\text { pada Bupati, } \\
\text { berupa laporan } \\
\text { semester } \\
\text { pertama dan } \\
\text { laporan } \\
\text { emester akhir } \\
\text { tahun }\end{array}$ & \\
\hline 2 & $\begin{array}{l}\text { Laporan } \\
\text { semester } \\
\text { pertama berupa } \\
\text { laporan realisasi } \\
\text { APBDesa }\end{array}$ & $\begin{array}{l}\text { Laporan } \\
\text { semester } \\
\text { pertama } \\
\text { merupakan } \\
\text { laporan } \\
\text { realisasi } \\
\text { APBDes }\end{array}$ & Sesuai \\
\hline 3 & $\begin{array}{l}\text { Laporan } \\
\text { si pelaksanaan } \\
\text { APBDesa } \\
\text { disampaikan } \\
\text { paling lambat } \\
\text { pada akhir } \\
\text { bulan Juli tahun } \\
\text { berjalan }\end{array}$ & $\begin{array}{l}\text { Laporan } \\
\text { alisasi } \\
\text { pelaksanaan } \\
\text { APBDes } \\
\text { disampaikan } \\
\text { paling lambat } \\
\text { akhir bulan } \\
\text { Juli } \\
\end{array}$ & Sesuai \\
\hline 4 & $\begin{array}{l}\text { Laporan } \\
\text { semester akhir } \\
\text { tahun } \\
\text { disampaikan } \\
\text { paling lambat } \\
\text { pada akhir } \\
\text { bulan Januari } \\
\text { tahun } \\
\text { berikutnya }\end{array}$ & $\begin{array}{l}\text { Laporan } \\
\text { semester akhir } \\
\text { tahun } \\
\text { disampaikan di } \\
\text { bulan Maret }\end{array}$ & $\begin{array}{l}\text { Tidak } \\
\text { sesuai }\end{array}$ \\
\hline
\end{tabular}

Sumber : Data Diolah (2020)

e. Pertanggungjawaban

Tabel 5 : Perbandingan

Pertanggungjawaban Dana Desa di
Pekon Kusa dengan Peraturan Menteri

Dalam Negeri Nomor 113 Tahun 2014

\begin{tabular}{|c|c|c|c|}
\hline $\begin{array}{l}\mathrm{N} \\
\mathrm{o}\end{array}$ & $\begin{array}{l}\text { Perturan } \\
\text { Menteri dalam } \\
\text { negeri nomor } \\
113 \text { tahun } 2016\end{array}$ & $\begin{array}{l}\text { Pengelolaan } \\
\text { keuangan Desa } \\
\text { di Pekon Kusa }\end{array}$ & $\begin{array}{l}\text { Sesu } \\
\text { ai / } \\
\text { Tida } \\
\text { k } \\
\text { sesu } \\
\text { ai }\end{array}$ \\
\hline 1 & $\begin{array}{l}\text { Kepala } \\
\text { a mes } \\
\text { laporan } \\
\text { pertanggungjaw } \\
\text { aban realisasi } \\
\text { pelaksanaan } \\
\text { APBDesa } \\
\text { kepada } \\
\text { Bupati/Walikota } \\
\text { setiap akhir } \\
\text { tahun anggaran }\end{array}$ & $\begin{array}{l}\text { Kepala } \\
\text { Des } \\
\text { a menyampaikan } \\
\text { laporan } \\
\text { pertanggungjaw } \\
\text { aban realisasi } \\
\text { pelaksanaan } \\
\text { APBDesa } \\
\text { ada kep } \\
\text { melalui } \quad \text { Camat } \\
\text { setiap akhir } \\
\text { tahun anggaran }\end{array}$ & $\begin{array}{l}\text { Sesu } \\
\text { ai }\end{array}$ \\
\hline 2 & $\begin{array}{l}\text { Laporan } \\
\text { pertanggungjaw } \\
\text { a-ban realisasi } \\
\text { pelaksanaan } \\
\text { APBDesa } \\
\quad \text { terdiri } \\
\text { dari pendapatan, } \\
\text { belanja, dan } \\
\text { pembiayaan }\end{array}$ & $\begin{array}{l}\text { Laporan } \\
\text { pertanggungjaw } \\
\text { a- ban realisasi } \\
\text { pelaksanaan } \\
\text { APBDes terdiri } \\
\text { dari pendapatan, } \\
\text { belanja, dan } \\
\text { pembiayaan }\end{array}$ & $\begin{array}{l}\text { Sesu } \\
\text { ai }\end{array}$ \\
\hline 3 & $\begin{array}{l}\text { Peraturan Desa } \\
\text { tentang laporan } \\
\text { pertanggungjaw } \\
\text { a- ban realisasi } \\
\text { pelaksanaan } \\
\text { APBDesa } \\
\text { dilampiri: } \\
\text { format Laporan } \\
\text { Pertanggungjaw } \\
\text { ab Realisasi } \\
\text { Pelaksanaan } \\
\text { APBDesa Tahun } \\
\text { Anggaran } \\
\text { berkenaan, } \\
\text { format Laporan }\end{array}$ & $\begin{array}{l}\text { Laporan } \\
\text { pertanggungjaw } \\
\text { ab- an realisai } \\
\text { pelaksanaan } \\
\text { APBDes terdiri } \\
\text { dari Laporan } \\
\text { Pertanggungjaw } \\
\text { aban Realisasi } \\
\text { Pelaksanaan } \\
\text { APBDes tah } \\
\text { un anggaran } \\
\text { berkenaan, } \\
\text { Laporan } \\
\text { Kekayaan Milik }\end{array}$ & $\begin{array}{l}\text { Sesu } \\
\text { ai }\end{array}$ \\
\hline
\end{tabular}




\begin{tabular}{|c|c|c|c|}
\hline & $\begin{array}{l}\text { Kekayaan Milik } \\
\text { Desa }\end{array}$ & $\begin{array}{l}\text { Desa dan } \\
\text { Laporan } \\
\text { Program } \\
\text { Pemerintah dan } \\
\text { Pemerintah } \\
\text { Daerah yang } \\
\text { masuk ke desa }\end{array}$ & \\
\hline 4 & $\begin{array}{l}\text { Laporan } \\
\text { real } \\
\text { isasi dan laporan } \\
\text { pertanggungjaw } \\
\text { a- ban realisasi } \\
\text { pelaksanaan } \\
\text { APBDesa } \\
\text { diinformasikan } \\
\text { kepada } \\
\text { masyarakat } \\
\text { secara tertulis } \\
\text { dan dengan } \\
\text { media } \\
\text { informasi yang } \\
\text { mudah diakses } \\
\text { oleh masyarakat }\end{array}$ & 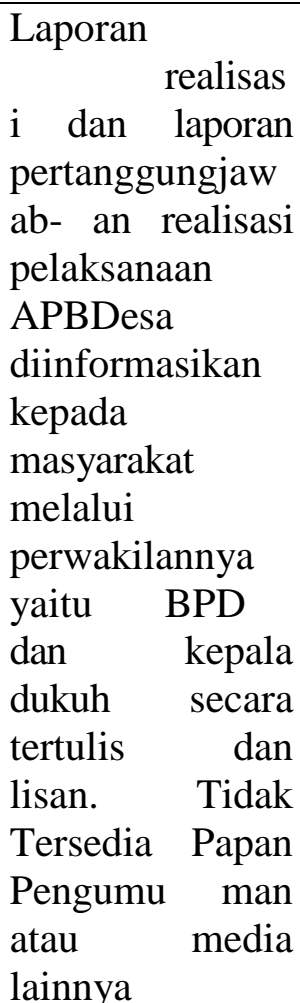 & $\begin{array}{l}\text { Tida } \\
\mathrm{k} \\
\text { Sesu } \\
\text { ai }\end{array}$ \\
\hline
\end{tabular}

\section{KESIMPULAN}

Secara umum proses pengelolaan Dana desa di Pekon Kusa sudah sesuai dengan Peraturan Menteri Dalam Negeri Nomor 113 Tahun 2014. Hanya saja dalam perencaaan APBDesa masih ada keterlambatan dalam memperoleh kesepakatan bersama. Kemudian dalam proses pelaksanaan juga masih ada ketentuan yang belum sesuai. Pertama, belum semua penerimaan dan pengeluaran dilakukan melalui rekening kas Desa. Proses pelaporan dan pertanggungjawaban juga belum sesuai kerena ada keterlambatan dalam penyampaian laporan realisasi dan pertanggungjawaban APBDesa. Hanya dalam proses penatausahaan yang seluruhnya sudah sesuai.

\section{DAFTAR PUSTAKA}

Peraturan Menteri Dalam Negeri Nomor. 113 Tahun 2014 tentang Pengelolaan Keuangan Desa. (2014). Menteri Dalam Negeri Republik Indonesia

Sujarweni, V.Wiratna. (2015). Akuntansi Desa Panduan Tata Kelola Keuangan. Yogyakarta: Pustaka Baru Press 